\title{
DETERMINASI TEKNOLOGI KOMUNIKASI PEDESAAN DAN PERKOTAAN DI WILAYAH MOJOKERTO
}

\author{
Ratnaningrum Zusiyana Dewi, Fatihatul Lailiyah \\ Ilmu Komunikasi Universitas Islam Majapahit Mojokerto \\ Jl. Raya Jabon KM. 0,7 Mojokerto, Jawa Timur 61364 \\ mustofalaili27@gmail.com
}

\begin{abstract}
Determination of technology is a major change that occurs in communities both in rural and urban areas. This is caused by the development of communication technology that moves very fast and dynamic. The changes that occur lead people to continuously adapt to changing patterns of daily life. This change causes a shift in values, how to interact, how to communicate, manners, manners, and other everyday cultures. This study aims to determine the determination of rural and urban communication technology in the district and city of Mojokerto. The results showed that the rural-urban communication system that occurred in the region. There are many kinds of communication that occur in each Kelurahan, the differences are very prominent in each region. These differences do not become a barrier for loyal people in communicating. Even though it is located in the city, the local population still upholds the culture and noble values of the local culture, such as gamelan, rice grass, death fees, community gatherings, patrols, recitation, and socialization about the dangers of dengue fever mosquitoes. The information media in this kelurahan comes from newspapers, magazines and bulletins, however the residents in this kelurahan seem to have less interest in buying the printed media, therefore the subscribers are approximately 72 residents, maybe this is due to the increasingly modern era and the population. who are very knowledgeable about technology.
\end{abstract}

Keywords: determinism of communication, rural and urban communication systems.

\begin{abstract}
Abstrak
Determinasi teknologi merupakan perubahan besar yang terjadi di masyarakat desa dan perkotaan. Dikarenakan oleh perkembangan teknologi komunikasi yang bergerak sangat cepat dan dinamis. Perubahan yang terjadi menggiring manusia untuk terus menerus beradaptasi terhadap perubahan pola kehidupan sehari hari. Perubahan ini menyebabkan pergeseran nilai, cara berinteraksi, cara berkomunikasi, adab, sopan santun, dan budaya keseharian lainnya. Penelitian ini bertujuan mengetahui determinasi teknologi komunikasi pedesaan dan perkotaan di kabupaten dan kota Mojokerto. Hasil penelitian menunjukkan sistem komunikasi pedesaan/perkotaan terdapat banyak ragam komunikasi di setiap Kelurahan. Perbedaan tidak menjadi penghalang bagi masyarakat dalam berkomunikasi. Meskipun masyarakat kota, masih menjunjung tinggi kebudayaan dan nilai luhur budaya, seperti karawitan, jumput beras, iuran kematian, kumpul warga, ronda, pengajian, sosialisasi bahaya nyamuk demam berdarah. Media informasi bersumber dari koran, majalah dan buletin, akan tetapi warga di kelurahan terlihat kurang memiliki minat untuk membeli media cetak tersebut, maka dari itu yang berlangganan kurang lebih 72 warga, mungkin hal ini disebabkan karena zaman yang semakin modern dan penduduk yang sudah sangat paham akan teknologi.
\end{abstract}

Kata Kunci: determinisme komunikasi, sistem komunikasi pedesaan dan perkotaan. 


\section{PENDAHULUAN}

Determinasi teknologi merupakan perubahan besar yang terjadi di masyarakat baik di desa maupun di perkotaan. Hal itu disebabkan oleh perkembangan teknologi komunikasi yang bergerak begitu sangat cepat dan dinamis Penemuan-penemuan baru, inovasi, dan perkembangan teknologi lain yang memudahkan kegiatan manusia, memberi pengaruh besar kepada perkembangan nilai nilai sosial, politik, ekonomi, pendidikan, dan lain lain.

Dalam Abidin (2014), berkembangnya teknologi, semakin banyak inovasi yang diciptakan, maka semakin canggih pula teknologi yang bisa kita pakai. Teknologi komunikasi modern bertebaran dimana mana. Masyarakat tidak bisa menghindari hal tersebut. Cepat atau lambat perubahan sosial akan segera tercipta. Teknologi menjadi salah satu agen berubahnya pola kehidupan sehari hari. Perubahan yang terjadi menggiring manusia untuk terus menerus beradaptasi terhadap perubahan pola kehidupa sehari hari. Perubahan ini menyebabkan pergeseran nilai, cara berinteraksi, cara berkomunikasi, adab, sopan santun, dan budaya keseharian lainnya.

Budaya dibentuk oleh cara orang berkomunikasi. Teknologi membentuk cara berpikir manusia, berperilaku di masyarakat, teknologi itu jugalah yang pada akhirnya akan mengarahkan manusia untuk bergerak dari satu abad teknologi ke abad teknologi yang lain. Teknologi komunikasi yang bergerak sangat cepat secara tidak langsung membentuk sistem komunikasi yang berimplikasi pada perubahan pola komunikasi masyarakat. Dimana Proses komunikasi memungkinkan pengirim (sender) memberi informasi ke penerima (receiver) dengan perantara media. Dalam hal ini, teknologi dipandang sebagai produk dan proses. Hardware dan software. Perangkat keras dan perangkat lunak. Keduanya bersama-sama berfungsi sebagai media (perantara) dalam proses komunikasi.
Teknologi komunikasi yang berkembang sangat cepat mau tidak mau mengharuskan setiap orang untuk selalu proakif dan adaptatif terhadap perkembangan teknologi (Surahman, 2016) .

Berbicara tentang teknologi komunikasi dan sistem komunikasi tidak bisa lepas dari sistem sosial. Dimana sistem komunikasi adalah bagian dari interaksi unsur-unsur dalam sebuah sistem sosial. Sebuah sistem sosial mempunyai sistem komunikasi sendiri yang nantinya bisa menjadi ciri khas sistem sosial. Menurut Usman (2013), komunikasi sebagai sebuah sistem yang tidak bisa berdiri sendiri. Komunikasi sebagai sebuah sistem terdiri dari beberapa elemen, diantaranya: elemen elemen komunikasi (komunikator, komunikan, pesan, media, timbal balik), atribut komunikasi yang dipakai, komunikasi antar personal di daerah tersebut, dan lingkungan sosial daerah itu sendiri.

Elemen elemen tersebut bersama-sama membentuk satu kesatuan sistem komunikasi yang saling mempengaruhi. Dalam skala yang lebih besar, sistem komunikasi juga tidak terpisahkan dari sistem politik, sosial, dan budaya sebuah daerah. Seperti misalnya kegiatan perpolitikan pilkada yang berbasis media sosial memiliki praktik detreminasi teknologi dalam proses komunikasi di dalamnya (Putra, 2011).

Perkembangan sistem komunikasi
tidak bisa lepas dari perkembangan determinasi teknologi komunikasi. Kebijakan pemerintah Indonesia yang memberikan sarana internet untuk seluruh kelurahan/RW di Indonesia disambut dengan antusias semua penduduk. Meskipun belum ada jaringan internet gratis di masing masing rumah, tetapi keberadaan jaringan internet di setiap balai desa cukup membantu penduduk dalam mengakses informasi. Akses internet telah menjadi kebutuhan warga. Tidak hanya untuk berselancar di media sosial, menyebarkan 
informasi, tetapi juga membantu kelancaran bisnis penduduk. Free wifi biasanya dipasang di area publik. Misalnya balai desa, puskesmas, sekolah, taman desa, dan destinasi wisata desa. Tujuannya adalah supaya banyak warga bisa mengakses internet dengan mudah dan gratis. Dengan begitu masyarakat akan semakin mudah mendapatkan informasi sesuai kebutuhan dan bisa mengembangkan usahanya.

Di kota dan kabupaten di wilayah Mojokerto, kebijakan pemasangan internet di ruang-ruang public baik di balai desa dan kelurahan dan taman-taman kota sudah berlangsung kurang lebih 5 tahun terakhir. Bupati Mojokerto Mustofa Kamal Pasha dan walikota Mas'ud Yunus mewajibkan di tiap wilayah desa kabupaten dan kelurahan kota Mojokerto untuk memasang internet di ruang-ruang publik guna memperlancar pekerjaan administrasi desa sekaligus memfasilitasi penduduk untuk mengakses internet secara gratis. Meskipun internet hanya dipasang di balai desa, atau di tamantaman kota secara umum sudah sangat membantu warga untuk bertukar informasi antar warga.

Dengan Adanya internet di ruang-ruang publik tentunya berpengaruh terhadap sistem komunikasi antar warga. Sistem komunikasi dan sistem sosial di wilayah tersebut akan mengalami banyak perubahan. Perkembangan teknologi komunikasi akan membawa masyarakat ke arah yang tak terduga. Berdasar uraian di atas, penelitian ini membahas tentangdeterminasi teknologi komunikasi pedesaan dan perkotaan di wilayah kabupaten dan Kota Mojokerto.

\section{Determinisme Teknologi}

Konsep determinisme teknologi pertama kali diungkapkan oleh McLuhan (2003), mengatakan bahwa perubahan yang terjadi dalam perkembangan teknologi sejak jaman dahulu sampai sekarang berpengaruh besar terhadap kehidupan bermasyarakat. Penemuan penemuan baru dan inovasi yang bertujuan untuk mempermudah kehidupan manusia, berpotensi mengubah kehidupan sosial

Dalam Kornblum (2000), hubungan antara teknologi dan masyarakat adalah merupakan hubungan yang saling mempengaruhi. Perkembangan teknologi mempengaruhi perkembagan masyrakat. Teknologi adalah kunci untuk mengendalikan perubahan di masyarakat, perubahan sosial di masyarakat dikendalikan oleh inovasi dan penemuan baru yang terus menerus terjadi di bidang teknologi. McLuhan mengatakan bahwa mesin/teknologi ciptaan manusia yang pada awalnya dibuat untuk mempermudah kehidupan manusia sehari hari, sekarang justru mesin mesin itulah yang mengontrol kehidupan manusia. Yang sekarang kita rasakan adalah sistem sosial di masyarakat selalu berkaitan erat dengan perkembangan teknologi.

Teknologi menjadi perpanjangan tangan manusia. Namun kemudahan yang diberikan oleh teknologi menjadi bumerang bagi kita sendiri. Kita menjadi sangat tergantung pada teknologi. Masyarakat dimanja oleh fasilitas yang diberikan oleh teknologi. Alat alat rumah tangga adalah contoh dari riuhnya perkembangan teknologi. Belum lagi alat transportasi berbasis tenaga listrik. Monorail, mobil listrik, MRT, dan lain lain. Teknologi komunikasi berbasis internet sangat terasa dalam kehidupan sehari hari. Perkembangan perangkat dan jejaring sosial 
secara otomatis mengubah cara berkomunikasi dan berinteraksi masyarakat (Kristiyono, 2015).

Media baru mendominasi perkembangan teknologi komunikasi di abad ini. Media lama yang bersandar pada media massa (televisi, radio, media cetak) tergerus oleh media baru yang berbasis jaringan/internet (Sukmi, 2015). Internet merupakan fasilitator dalam menyampaikan berbagai pesan. Sehingga era media baru memunculkan fenomena keterlimpahan informsi. Informasi disampaikan melalui media berbasis teknologi komunikasi (Rianto, 2016). Dalam hal ini adalah smartphone, gadget, dan lain lain. Media merupakan pesan itu sendiri sehingga dapat memfasilitasi prosespenyampaian pesan. Pesan yang disampaikan oleh media (perangkat komunikasi) identik dengan keinginan, perasaan, dan mimpi mimpi sender (pengirim) dan diterima dengan baik pula oleh receiver (penerima). Fungsi audio (pendengaran), visual (penglihatan), maupun audio visual, diterjemahkan dengan rapih oleh smartphone (Nisa, et al., 2019).

\section{Perubahan Sosial}

Perubahan Sosial adalah proses perubahan tatanan atau struktur dalam masyarakat. Struktur yang dimaksud mencakup pola pikir menjadi lebih inovatif, sikap, dan juga kehidupan sosial sehingga memperoleh penghidupan yang lebih baik dan bermartabat. Sebenarnya perubahan menjadi satu hal pasti yang bakal terjadi dalam kehidupan masyarakat. Dimana perubahan-perubahan dalam masyarakat bisa dikenali dengan melakukan perbandingan dan menelaah kondisi masyarakat di suatu waktu dengan waktu lainnya.

Efek dari detreminasi teknologi memunculkan keterlimpahan informasi terutama dalam pemanfaatan media sosial. Media baru yang berwujud media sosial membawa perubahan sosial yang berdampak signifikan terhadap audien. Seperti misalnya, media baru melakukan praktik komodifikasi waktu dari audiens (Setiyaningsih, et al., 2019). Selain itu dalam Rohi, et al. (2017), efek detreminasi dalamaspek ekonomi adalah meningkatkan kompetisi dalam pencapaian perekonomian yang berbasis teknologi. Teori tentang masyarakat dan perubahan sosial tidak dapat dipisahkan. Namun juga harus diakui bahwa tidak ada satu teori perubahan sosial yang benar-benar mencukupi untuk membaca perubahan-perubahan yang terjadi dalam masyarakat termasuk apa yang selama ini sering diuangkapkan, yakni apa yang disebut "grand theory". Kata Etzioni, "grand theories" tidak memberikan bimbingan yang mencukupi untuk riset sosiologi tetapi tidak ada perubahan sosial yang modern telah menggantikannya (Harun, 2011).

Konsep perubahan sosial maupun perubahan budaya, pada umumnya dua konsep tersebut dibedakan, yaitu masingmasing perubahan dikaitkan dengan aspek yang berbeda, yang satu berkaitan dengan bidang budaya yang berubah dan yang satunya dengan bidang sosial. Pada dasarnya perubahan sosial dan perubahan budaya merupakan konsep yang sebenarnya saling berkaitan satu sama lain meskipun mempunyai perbedaan. Perubahan sosial mencakup perubahan dalam segi struktur dan hubungan sosial, sedangkan perubahan budaya mencakup perubahan dalam segi budaya masyarakat. Octavianto (2014), kritik atas detreminasi bahwa dapat dikendalikan dengan kekuatan konten lokal. Detreminasi teknologi dapat dihindarkan ketika mampu mengendalikan media baru untuk dimanfaatkan dalam berkomunikasi. Pada media elektronik, melalui televisi lokal pemberdayaan untuk literasi dapat dilakukan dengan pemanfaatan konten lokal. Seperti dalam Setiyaningsih (2016), desain konten lokal dalam televisi lokal di Kota Malang mampu membentuk citra pariwisata kuliner. 
Perubahan dalam distribusi kelompok usia, tingkat pendidikan, hubungan sosial antar etnis yang bermukim dalam satu wilayah, peran perempuan dalam organisasi politik dan lain-lain adalah contoh dari perubahan sosial. Triono, et al, (2017), menyebutkan bahwa perubahan sosial di era media baru berawal dari pemanfaatan website sebagai pintu komunikasi. Desain web site merupakan bagian dari pesan untuk berkomunikasi di media baru. Sedangkan perubahan budaya meliputi penemuan teknologi komputer dan penciptaan seni tari modern dan lain-lain. Tetapi kedua konsep perubahan tersebut saling berkaitan, misalnya perubahan peran perempuan dalam masyarakat berkaitan dengan adanya perubahan nilai kedudukan perempuan. Jadi fenomena suatu perubahan di dalamnya akan mencakup aspek sosial dan budaya sehingga perbedaan istilah di antara keduanya sering kali tidak terlalu diperhatikan (Cahyono, 2016).

Perubahan sosial mengacu pada adanya pergantian dalam hubungan sosial dan ide-ide kultural, sehingga dalam hal ini konsep sosial dan budaya menjadi konsep yang saling berkitan dalam terjadinya suatu perubahan. Perubahan dalam ide dan nilai secara singkat akan mengarah pada terjadinya perubahan dalam hubungan sosial, dan sebaliknya perubahan dalam pola hubungan sosial akan menuju pada adanya perubahan nilai dan norma (Arnawa, 2012). Menurut Gilin perubahan sosial merupakan suatu variasi atau sesuatu yang lain yang timbul dari cara-cara hidup yang telah diterima. Di mana sesuatu yang baru tersebut dapat disebabkan perubahan dalam kondisi geografis maupun komposisi penduduk. Perubahan sosial dapat pula mempunyai pengertian sebagai adanya faktor eksternal dan internal yang mempengaruhi kehidupan manusia, seperti yang dikemukakan oleh Samuel Koenig. Hal tersebut berarti bahwa perubahan sosial merujuk pada adanya modifikasi-modifikasi dari faktor eksternal atau internal dalam pola-pola kehidupan manusia (Kamanto, 2000).

\section{METODE PENELITIAN}

Penelitian ini dilakukan dengan pendekatan deskriptif kualitatif, yaitu penelitian berdasar penggambaran, dan menguraikan berdasar fakta dan data yang ada. Data data tersebut dikompilasi, disusun, sehingga menghasilkan kesimpulan yang tepat. Teknik pengambilan data yang dipakai adalah wawancara, observasi dan dokumentasi. Wawancara dilakukan di kota dan kabupaten Mojokerto kepada 5 informan. Sebelumnya dilakukan observasi untuk melihat kondisi daerah terlebih dahulu. Lalu melakukan analisis data secara kualitatif dengan Miles dan Huberman (Sugiyono, 2017). Menurut miles dan Huberman, kegiatan analisis terdiri dari tiga alur kegiatan yang terjadi secara bersamaan, yaitu reduksi data, penyajian data, dan penarikan kesimpulan/verivikasi. Terjadi secara bersamaan berarti reduksi data, penyajian data, dan penarikan kesimpulan/verivikasi sebagai sesuatu yang saling jalin menjalin merupakan proses siklus dan interaksi pada saatsebelum, selama, dan sesudah pengumpulan data dalam bentuk sejajar yang membangun wawasan umum yang disebut analisis.

\section{HASIL DAN PEMBAHASAN}

\section{Hasil}

Desa Kertosari merupakan salah satu Desa yang berasal dari wilayah Kecamatan Kutorejo Kabupaten Mojokerto yang mayoritas masyarakat bermata pencaharian petani, wiraswasta, dan peternak dengan karakter masyarakat sesuai adat timur yaitu sopan, beretika dan religious, jumlah penduduk yang terus bertambah dari tahun ke tahun sehingga merupakan daerah yang berpenduduk sangat padat dengan tingkat pendidikan yang bervariasi mulai tamat SD sampai dengan Perguruan Tinggi. 
Adapun Cara berkomunikasi masyarakat kertosari juga sangat sederhana, dengan melalui gethok tular yakni dari surat lalu mulut kemulut warga desa kertosari. Hal ini membuktikan bahwa masyarakat Desa juga masih terbilang tradisional akan tetapi masyarakat saat ini juga mengikuti perkembangan teknologi yang semakin modern dan canggih yakni adanya tekephone genggam dengan berbagai jenis type dan beragam fungsinya. Sehingga ada sebagian dusun yang masih menggunakan gethok tular dan ada juga yang menggunakan media modern untuk mengundang masyarakat berkumpul. Mayoritas yang menggunakan gethok tular yakni masyakarat yang usia lanjut dan bapak-bapak yang masih menggunakan hal tersebut sebagai komunikasi antar warganya. Sedangkan para remaja sudah menggunakan media modern seperti telephon genggam dengan aplikasi media sosial yakni whats ap yang sering digunakan remaja untuk berkumpul membahas acara atau kegiatan yang akan diadakan di Desa Kertosari.

Adapun Media yang di gunakan oleh masyarkat Desa Kertosari yakni tradisi yang masih melekat dan tetap terjaga oleh masyarakat kertosari sampai dengan saat ini, antara lain Media Rakyat dan Media Tradisional. Media tradisional yang masih ada dan di pertahankan yakni Bedug dan trong-trong(kentongan) dimana keduanya memiliki fungsi yang berbeda. Bedug yang digunakan sebagai alat untuk penanda masuknya waktu sholat dan untuk merayakan hari raya idul fitri maupun idul adha. Trongtrong (Kentongan) digunakan untuk penanda kematian,biasanya dipukul sebanyak 5-7 kali untuk pertanda duka atau kematian setelah itu menggunakan microfon yang ada `di masji`d. Jadi sampai sekarang masyarakat masih menggunakan kentongan sebagai media penanda berduka. Sedangkan Media Rakyat yang digunakan oleh masyarakat Kertosari diantaranya Media warga madding yang ada dibalai desa, dimana berfungsi sebagai saluran alternatif dan sarana untuk memberikan informasi kepada masyarakt dalam mengemukakan akan kebutuhan dan kepentingan masyarakat .

\section{Pembahasan}

\section{Sistem jaringan Komunikasi antar masyarakat dan Media dan Seni Tradisional}

Komunikasi antar masyarakat Desa Kertosari masih menggunakan media lisan yang bisa disebut dengan gethok tular, jadi saat hari minggu akan diadakan kerja bakti membersihkan selokan dan seluruh kampung maka Pak lurah akan memberitahu lewat perbincangan secara langsung kepada tokoh masyarakat kemudian ketua RT akan mendatangi rumah warga satu persatu dan berita tersebut tersebar luas secara lisan melalui pembicaraan yang langsung tanpa perantara media modern. Akan tetapi seiring dengan perkembangan zaman sekarang,pak lurah juga menggunakan media komunikasi seperti handphone untuk memberitahukan untuk di adakannya gotong royong setiap dusun atau kampungnya masing-masing,jadi memeritahukan melalui handphone kepada ketua RT masing-masing kemudian ketua RT menyalurkan informasi tersebut tetap denagn menemui warganya satu persatu jadi tanpa menggunakan handphone. Begitupula saat akan dia adakannnya kediatang tradisi jawa seperti megengan,setiap warga memanggil warganya untuk berkumpul dirumahnya dengan media lisan secara langsung menemui tetangganya secara door to door. 
Media yang digunakan oleh masyarakat Desa Kertosari ada dua media yakni media tradisional dan media modern, sedangkan untuk media tradisional yakni: a) bedug yang digunakan sebagai alat untuk penanda masuknya waktu sholat dan untuk merayakan hari raya idul fitri maupun idul adha. b) Trong-trong (Kentongan) digunakan untuk penanda kematian,biasanya dipukul sebanyak 5-7 kali untuk pertanda duka atau kematian setelah itu menggunakan microfon yang ada `di masji`d. Jadi sampai sekarang masyarakat masih menggunakan kentongan sebagai media penanda berduka. c) Tradisi Megengan. Tradisi megengan ini merupakan salah satu bentuk tradisi dan ritual yang dilaksanakan secara turun-temurun yang dilaksanakan untuk memohon kepada Allah agar diberi kekuatan lahir dan batin dalam menghadapi dan melaksanakan puasa di bulan Ramadhan serta untuk mengirim doa atau mendoakan para leluhur yang telah meninggal dunia. Tradisi megengan ini merupakan tradisi Islam, karena tradisi ini dilakukan dalam rangka menyambut datangnya bulan suci Ramadhan. Dalam megengan ini, umat Islam (masyarakat yang melaksanakan megengan) mengharap kepada Allah swt agar diberi kekuatan lahir dan batin dalam melaksanakan puasa Ramadhan juga mendoakan leluhur dan dan keluarga yang sudah meninggal

Sehubungan dengan tradisi megengan ada yang sangat khas dalam tradisi ini adalah kue apem. Kue apem ini sebenarnya adalah ungkapan permintaan maaf secara tidak langsung kepada para tetangga. Menurut cerita bahwa tradisi ini diperkenalkan oleh Sunan Kalijaga pada saat penyebarab agama Islam di Jawa, terutama Jawa Tengah . Sunan Kalijaga ingin menganjurkan budaya meminta maaf atas segala kesalahan yang mungkin pernah dilakukan, namun hal ini bukan perkara yang mudah untuk dilakukan karena adat/budaya Jawa untuk meminta maaf adalah sesuatu yang bernilai tinggi karena menyangkut harga diri. Maka Sunan Kalijaga mengajarkannya dengan cara membuat kue yang berbahan dasar dari beras ketan putih, dicampur dengan santan, gula dan garam. Setelah kue matangmaka Sunan Kalijaga mengajak masyarakat sekitar untuk berkumpul dan dan mengajarkan arti dari kue itu kepada masyarakat. Kue tersebut kemudian diberi nama kue apem.

Apem berasal dari kata afwun yang berarti meminta maaf dan memberi maaf. Dn menurut cerita, karena dalam masyarakat Jawa tidak mengenal huruf " $F$ ", maka kata afwun berubah menjadi apwum, kemudian diselaraskan dengan lidah orang Jawa gar mudah mengucapkannya sehingga akhirnya disebut apem. Dilihat dari bahan dasar ketika Sunan Kalijaga membuat kue tersebut juga melambangkan kesucian. Beras ketan putih, dimana warna putih meambangkan kesucian. Santan yang merupakan sari buah kelapa yang bermanfaat semua bagiannya melambangkan sari atau ketulusan manusia. Gula dan garam melambangkan perasaan hati manusia. Maka bila bahan-bahan tersebut dijadikan satu, makna simboliknya adalah kesucian dan ketulusan perasaan hati manusia.Tradisi ini akhirnya berjalan setia hingga saat ini di masyarakat Jawa. Kemudian terdapat juga menu tambahan dalam tradisi ini berupa nasi golong yang dalam masyarakat Desa Kertosari berasal dari kata gemolong berarti berlimpah ruah, mempunyai makna doa kepada Allah SWT agar diberi rezeki yang gemolong atau berlimpah ruah. Yang mempunyai maksud dan tujuan untuk mendapatkan keberkahan. 
Tradisi Selapan, dalam tradisi Jawa selapanan dimaksudkan sebagai suatu upacara syukur atas kelahiran bayi yang tepat berusia 35 hari. Misalnya, bayi lahir pada Minggu Kliwon maka pesta selapanan tepat pada hari Minggu Kliwon. Seperti kita ketahui bahwa di Jawa orang masih menghitung hari menurut hitungan 7 hari dalam 1 minggu dalam Kalender Masehi yang mengikuti hitungan matahari (sapta wara: Minggu/Ahad, Senin, Selasa, Rabu, Kamis, Jumat, Sabtu) dan hitungan 5 hari dalam 1 pasaran dalam Kalender Jawa yang mengikuti hitungan bulan (pancawara : Pahing, Pon, Wage,Kliwon, Legi). Jadi, selapan $=7 \times 5=35$ hari.

Acara selapanan bayi dimaksudkan untuk menyatakan rasa syukur kepada Tuhan Sang Pencipta atas berkat keselamatan yang diberikan kepada bayi dan ibunya. Sejak acara sepasaran sampai selapanan, sanak saudara, tetangga dan teman-teman datang silih berganti memberikan ucapan selamat dan sesuatu hadiah atas kelahiran si bayi. Sekarang rasa syukur, terima kasih dan kegembiraan itu diungkapkan dengan cara berbagi dengan sanak saudara, tetangga, dan teman dalam upacara selapanan bayi.

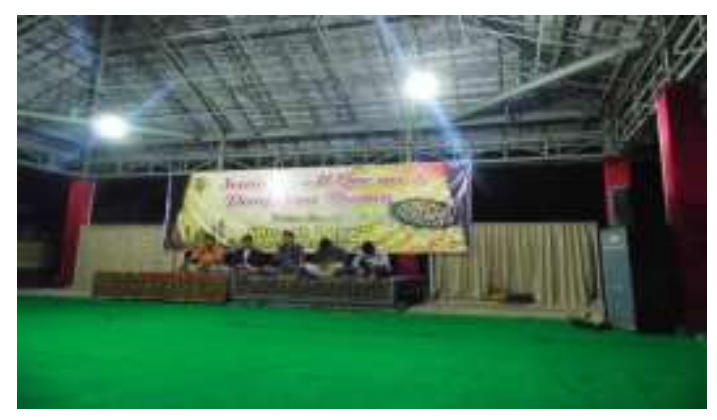

Gambar Ruwah Desa Kertosari di Balai Desa

Tradisi Ruwah Desa yang setiap tahunnya di adakan oleh masyarakat Desa Kertosari dan di adakan pengajian yang berguna untuk meningkatkan kerukunan masyarakat serta jreligi masyarakat. Tradisi Ruwah Desa juga bertujuan untuk meminta perlindungan kepada allah untuk desanya agar terhindar dari bencana dan masalah,selain itu bancaan desa dalam bahasa jawa, yang berguna untuk mendoakan desa kertosari supaya masyarakatnya makmur dan sejahtera. Serta hasil panen masyarakat bisa melimpah dan dimudahkan rizkinya bagi semua masyarakat Desa Kertosari.

\section{Kondisi Sosial Masyarakat}

Dengan adanya perubahan dinamika politik dan sistem politik di Indonesia yang lebih demokratis, memberikan pengaruh kepada masyarakat untuk menerapkan suatu mekanisme politik yang dipandang lebih demokratis. Dalam konteks politik lokal Desa Kertosari, hal ini tergambar dalam pemilihan kepala desa dan pemilihan-pemilihan lain (pilleg, pilpres, pemillukada, dan pemilugub) yang juga melibatkan warga masyarakat desa secara umum. Khusus untuk pemilihan kepala desa Kertosari, sebagaimana tradisi kepala desa di Jawa, biasanya para peserta (kandidat) nya adalah mereka yang secara trah memiliki hubungan dengan elit kepala desa yang lama. Hal ini tidak terlepas dari anggapan masyarakat banyak di desa-desa bahwa jabatan kepala desa adalah jabatan garis tangan keluarga-keluarga tersebut. Fenomena inilah yang biasa disebut pulung dalam tradisi jawa- bagi keluarga-keluarga tersebut.

Jabatan kepala desa merupakan jabatan yang tidak serta merta dapat diwariskan kepada anak cucu. Mereka dipilih karena kecerdasan, etos kerja, kejujuran dan kedekatannya dengan warga desa. Kepala desa bisa diganti sebelum masa jabatannya habis, jika ia melanggar peraturan maupun 
norma-norma yang berlaku. Begitu pula ia bisa diganti jika ia berhalangan tetap. Karena demikian, maka setiap orang yang memiliki dan memenuhi syarat-syarat yang sudah ditentukan dalam perundangan dan peraturan yang berlaku, bisa mengajukan diri untuk mendaftar menjadi kandidat kepala desa. Fenomena ini juga terjadi pada pemilihan desa Kertosari pada tahun 2013. Pada pilihan kepala desa ini partisipasi masyarakat sangat tinggi, yakni hampir 90\%. Tercatat ada dua kandidat kepala desa pada waktu itu yang mengikuti pemilihan kepala desa. Pilihan kepala Desa bagi warga masyarakat Desa Kertosari seperti acara perayaan desa.

Setelah proses-proses politik selesai, situasi desa kembali berjalan normal. Hiruk pikuk warga dalam pesta demokrasi desa berakhir dengan kembalinya kehidupan sebagaimana awal mulanya. Masyarakat tidak terus menerus terjebak dalam sekatsekat kelompok pilihannya. Hal ini ditandai dengan kehidupan yang penuh tolong menolong maupun gotong royong. Walaupun pola kepemimpinan ada di Kepala Desa namun mekanisme pengambilan keputusan selalu ada pelibatan masyarakat baik lewat lembaga resmi desa seperti Badan Perwakilan Desa maupun lewat masyarakat langsung. Dengan demikian terlihat bahwa pola kepemimpinan di Wilayah Desa Kertosari mengedepankan pola kepemimpinan yang demokratis.

Berdasarkan deskripsi beberapa fakta di atas, dapat dipahami bahwa Desa Kertosari mempunyai dinamika politik lokal yang bagus. Hal ini terlihat baik dari segi pola kepemimpinan, mekanisme pemilihan kepemimpinan, sampai dengan partisipasi masyarakat dalam menerapkan sistem politik demokratis ke dalam kehidupan politik lokal.
Tetapi terhadap minat politik daerah dan nasional terlihat masih kurang antusias. Hal ini dapat dimengerti dikarenakan dinamika politik nasional dalam kehidupan keseharian masyarakat Desa Kertosari kurang mempunyai greget, terutama yang berkaitan dengan permasalahan, kebutuhan dan kepentingan masyarakat secara langsung.

Berkaitan dengan letaknya yang berada diperbatasan Desa dengan kawasan pondok Pesantren, sehingga budaya masyarakat yang Agamis sangat terasa di Desa Kertosari. Dalam hal kegiatan agama Islam misalnya, suasananya sangat dipengaruhi oleh aspek budaya dan sosial Jawa. Hal ini tergambar dari dipakainya kalender Jawa/ Islam, masih adanya budaya Ruwah deso, slametan, tahlilan, mithoni, tingkepan dan lainnya, yang semuanya merefleksikan sisi-sisi akulturasi budaya Islam dan Jawa.

Dengan semakin terbukanya masyarakat terhadap arus informasi, hal-hal lama ini mulai mendapat respon dan tafsir balik dari masyarakat. Hal ini menandai babak baru dinamika sosial dan budaya, sekaligus tantangan baru bersama masyarakat Desa Kertosari. Dalam rangka merespon tradisi lama ini telah mewabah dan menjamur kelembagaan sosial, politik, agama, dan budaya di Desa Kertosari. Tentunya hal ini membutuhkan kearifan tersendiri, sebab walaupun secara budaya berlembaga dan berorganisasi adalah baik tetapi secara sosiologis ia akan beresiko menghadirkan kerawanan dan konflik sosial.

Dalam catatan sejarah, selama ini belum pernah terjadi bencana alam dan sosial yang cukup berarti di Desa Kertosari. Isu-isu terkait tema ini, seperti kemiskinan dan bencana alam, tidak sampai pada titik kronis yang membahayakan masyarakat dan sosial. 
Komunikasi yang ada di Desa Kertosari yakni masih menggunakan komunikasi yang disebut dengan gethok tular. Dimana komunikasi antar warganya ini saat akan diadakan sebuah kegiatan kemasyarakatan masih menggunakan komunikasi gethok tular yakni Getok tular berarti dari mulut ke mulut (tentang penyebaran berita dan sebagainya). Dan ketika desa mengadakan kegiatan yakni menggunkan komunikasi kelompok yakni komunikasi tersebut terjadi di forum desa yang di pimpin kepala desa dan yang di ikuti oleh para kepala dusun dan jajarannya. Proses komunikasi yang terjadi di Desa Kertosari dari pihak atas ke masyarakat

\section{Kelurahan Pulorejo}

Kelurahan Pulorejo Kecamatan Prajurit Kulon Kota Mojokerto mempunyai luas wilayah 142,35 Ha. Jumlah penduduk laki laki pada tahun 2017 berjumlah 3.768 jiwa sedangkan jumlah penduduk perempuan 3.753 jiwa, Adapun Jumlah KK laki-laki sebanyak $2004 \mathrm{KK}$, sedangkan perempuan berjumlah 276 KK (Cerai Hidup Atau Cerai Mati) dengan total $2280 \mathrm{KK}$. Kelurahan Pulorejo belum bisa di katakan sebagai memiliki icon khusus yang bisa diangkat namun masih bisa menjadi sala satu destinasi wisata dari potensi-potnsi SDA dan SDM yang bisa di kembangkan untuk lebih mengangkat wilayah kelurahan Pulorejo.

\footnotetext{
Kelurahan Pulorejo memiliki ruang publik sebagai sarana edukasi bagi masyarakat seperti, hutan kota yang dilengkapi dengan fasilitas free $\mathrm{Wi}-\mathrm{Fi}$, selain itu pula kampung bahasa inggris yang ada di setiap RT dengan kurang begitu maksimal karena hanya yang mengajar dari mahasiswa di wilayah masing-masing RT, begitu juga dengan minimnya peminat yang di sebabkan kurangnya publikasi kepada masyarakat. Media informasi pada kelurahan ini bersumber dari koran, majalah dan buletin, akan tetapi warga di kelurahan ini terlihat
}

kurang memiliki minat untuk membeli media cetak tersebut, maka dari itu yang berlangganan kurang lebih 72 orang, mungkin hal ini disebabkan karena zaman yang semakin modern dan penduduk yang sudah sangat paham akan teknologi sehingga masyarakat cenderung lebih suka mengakses informasi lewat sosial media.

\section{PENUTUP}

\section{Simpulan dan Saran}

Sistem komunikasi yang terjadi pedesaan/perkotaan yang terjadi diwilayah tersebut. Terdapat banyak sekali ragam komunikasi yang terjadi di setiap Kelurahan, perbedaan sangat menonjol terjadi pada setiap wilayah. Perbedaan tersebut tidak menjadi penghalang bagi setia masyarakat dalam melakukan komunikasi. Kelurahan Pulorejo belum memiliki icon khusus yang bisa diangkat menjadi sebuah daerah wisata untuk lebih mengangkat wilayah kelurahan Pulorejo. Kelurahan Pulorejo memiliki ruang publik untuk sarana edukasi bagi masyarakat seperti, hutan kota yang dilengkapi dengan fasilitas free Wi-Fi, lalu ada pula kampung bahasa inggris yang ada di setiap RT dengan tenaga kerja yang kurang maksimal karena hanya didapatkan dari mahasiswa di wilayah masing-masing begitu juga dengan minim nya peminat.

Pada kelurahan Pulorejo mayoritas penduduk adalah lulusan SMA Sederajat, dari data tersebut dapat disimpulkan bahwa penduduk kelurahan Pulorejo mudah diajak untuk berpikir lebih maju. Hal ini merupakan bukti bahwa penduduk kelurahan pulorejo peduli akan pendidikan. Penduduk kelurahan Pulorejo sebagian besar bermata pencaharian sebagai karyawan swasta, sisanya pedagang, PNS lalu ada pula yang menjadi buruh tani. Meskipun letaknya di kota penduduk setempat masih menjunjung tinggi kebudayaan dan nilai-nilai luhur budaya setempat, seperti karawitan, jumput beras, iuran kematian, kumpul warga, ronda, pengajian, lalu sosialisasi tentang bahaya 
nyamuk demam berdarah. Media informasi pada kelurahan ini bersumber dari koran, majalah dan buletin, akan tetapi warga di kelurahan ini terlihat kurang memiliki minat untuk membeli media cetak tersebut, maka dari itu yang berlangganan kurang lebih 72 warga, mungkin hal ini disebabkan karena zaman yang semakin modern dan penduduk yang sudah sangat paham akan teknologi.

\section{DAFTAR PUSTAKA}

Abidin, N. A. Z. (2014). Kelantangan Di Laman Media Sosial Bukti Emosi Atasi Ilmu: Budaya Membaca Mampu Lahirkan Masyarakat Berfikir Sebelum Bertindak. Jurnal Budaya 4(1). 43-56., 4(1), 43-56.

Arnawa, I. K. (2012). Determinasi Latihan Kerja, Kompetensi Kewirausahaan dan Bimbingan Karier terhadap Kesiapan Kerja Siswa Smk Negeri Kelompok Teknologi Dan Rekayasa di Kabupaten Buleleng. Jurnal Administrasi Pendidikan Indonesia, 3(2).

Cahyono, A. S. (2016). Pengaruh media sosial terhadap perubahan sosial masyarakat di Indonesia. Jurnal Publiciana, 9(1), 140-157.

Harun Rochajat, A. elvinaro. (2011). Komunikasi pembangunan Perubahan Sosial. Raja Grafindo.

Kamanto, S. (2000). Pengantar Sosiolog. Jakarta: LPE-UI.

Kornblum, W. (2000). Sociology in a changing world. Harcourt College Publisher.

Kristiyono, J. (2015). Budaya Internet: Perkembangan Teknologi Informasi Dan Komunikasi Dalam Mendukung Penggunaan Media Di Masyarakat. Scriptura, 5(1), 23-30.

McLuhan, M. (2003). Understanding Media:
The Extension of Man. In Understanding Media: The Extension of Man. Gingko Press.

Nisa Nurmauliddiana, A., Hidayat, D. R., \& Wibowo, K. A. (2019). Big Data dan Literasi Digital dalam Menghadapi Information Overload. Communication and Information Beyond Boundaries, 30(1), 143-156.

Octavianto, A. W. (2014). Strukturasi Giddens dan Social Construction of Technology (SCoT) Sebagai Pisau Analisis Alternatif Penelitian Sosial Atas Teknologi Media Baru. Ultimacomm: Jurnal Ilmu Komunikasi., 6(2), 41-57.

Putra, A. M. (2011). Media Baru dan Fenomena Komunikasi Politik pada Pemilukada di Provinsi Banten 2011. Ultimacomm: Jurnal Ilmu Komunikasi, 3(2), 23-34.

Rianto, P. (2016). Media baru, visi khalayak aktif dan urgensi literasi media. Jurnal Komunikasi Ikatan Sarjana Komunikasi Indonesia, 1(2), 90-96.

Rohi, R., \& Jehamat, L. (2017). Perubahan Sosial Ekonomi Masyarakat di Kelurahan Oesapa dan Sekitarnya Akibat Hadirnya Pemondokan di Kawasan Pemukiman. Jurnal Inovasi Kebijakan, 2(1), 66-80.

Setiyaningsih, L. A., \& Jatmikowati, S. H. (2019). Media Baru Dalam Komodifikasi Waktu Luang Ibu Rumah Tangga. ETTISAL: Journal of Communication, 4(1), 23-32.

Setiyaningsih, L. A. (2016). Desain Konsep Tentang Konten Lokal Pada Televisi Lokal Untuk Mengembangkan Wisata Kuliner Kota Malang. Jurnal Nomosleca, 2(2), 1-19. https://doi.org/10.26905/nomosleca.v2i 2.1198 
JURNAL NOMOSLECA

Volume 6 Nomor 2, Oktober 2020

Sugiyono. (2017). Metode Penelitian Kuantitatif Kualitatif dan $R \& D$. Alfabeta.

Sukmi, S. N. (2015). RETHINKING TEORI KOMUNIKASI DALAM KONTEKS MEDIA BARU (Telaah Pemikiran Holmes tentang Komunikasi, Teknologi dan Masyarakat). Cakrawala, 4(1).

Surahman, S. (2016). Determinisme Teknologi Komunikasi dan Globalisasi Media Terhadap Seni Budaya Indonesia. REKAM: Jurnal Fotografi, Televisi,
Dan Animasi, 12(1), 31-42.

Triono, M. A., \& Setiyaningsih, L. A. (2017). Desain Disonansi Kognitif Sebagai Faktor Anteseden Untuk Penguatan Kualitas Informasi Pada Website. Seminar Nasional Sistem Informasi, 1(1), 71-79. http://eprints.unmer.ac.id

Usman, I. (2013). Kepribadian, komunikasi, kelompok teman sebaya, iklim sekolah dan perilaku bullying. Humanitas: Jurnal Psikologi Indonesia, 10(1), 4960. 